\title{
CAFFEINE IMPROVES THE DEVELOPMENTAL COMPETENCE OF PARTHENOGENETIC EMBRYOS DERIVED FROM AGING PORCINE OOCYTES
}

\author{
Nguyen Thi Thuy Van ${ }^{1,2^{*}}$, Pham Truong Duy ${ }^{1,2^{*}}$, Nguyen Van Thuan ${ }^{1,2}$, Bui Hong Thuy ${ }^{1,2 \bowtie}$ \\ ${ }^{1}$ Cellular Reprogramming Lab, School of Biotechnology, International University, Ho Chi Minh City, Vietnam \\ ${ }^{2}$ Vietnam National University, Ho Chi Minh City, Vietnam \\ * These authors contributed equally to this work \\ ${ }^{\square}$ To whom correspondence should be addressed. E-mail: bhthuy@hcmiu.edu.vn
}

Received: 09.8.2019

Accepted: 10.12.2019

\section{SUMMARY}

Oocytes are committed to deterioration in quality as they aged due to a long duration manipulation which leads to the reduced success rate of somatic cell nuclear transfer (SCNT). Caffeine with an effect to maintain the maturation-promoting factor (MPF) from the metaphase of oocytes is expected to enhance the quality of the aging oocytes. To investigate the timely treatment of caffeine to rescue aging oocytes, caffeine was supplemented after in vitro maturation (IVM) or during metaphase I - metaphase II (MI - MII) transition. First, the effect of caffeine after IVM of oocytes was examined. After IVM for $42 \mathrm{~h}$, oocytes were left for aging within 6 or 8 hours in supplement with various concentrations of caffeine $(0,5$ and $10 \mathrm{mM})$, and then, examined the quality of embryo from aged oocyte through parthenogenesis activation. We found that $5 \mathrm{mM}$ caffeine for the first 6 hours of aging process was suggested to improve the early development of parthenogenetic diploid embryos. However, the cytoplasmic homogeneity is significantly reduced in aging oocyte compared to fresh oocyte and it could not be improved by caffeine treatment. Next, the effect of caffeine during MI - MII transition of oocyte was examined. Caffeine was supplemented during MI - MII transition $(27-42 \mathrm{~h})$ of IVM. Then mature oocytes were left for aging within $6 \mathrm{~h}$ to examine on aging porcine oocyte quality via parthenogenesis embryos. The results indicated that $5 \mathrm{mM}$ caffeine during MI-MII transition could efficiently rescue aged oocytes and improve the development of embryos derived from aging oocytes to four-cell, eight-cell and blastocyst stage as compared to fresh oocytes. Especially, these aged oocytes treated by caffeine could improve the cytoplasmic homogeneity in embryos and the quality of blastocysts by increasing cell number similar to fresh oocytes.

Keywords: caffeine, mature oocyte, aging oocyte, electro-activation, parthenogenetic embryo.

\section{INTRODUCTION}

Somatic cell nuclear transfer (SCNT) is a method by which cloned embryos can be produced using differentiated cells. This technique has various applications including meat production, drug synthesis, regenerative medicine and genetic conservation of endangered animals. Despite their potential impacts, animal cloning is still a big challenge to scientists as the success rate of SCNT is still extremely low, even with great support from high technology. One of the main causes was the decreased quality of oocyte, indicated as "aging" oocytes, during the processes of enucleation and somatic cells nuclear transfer. Thus, the prevention of oocyte from aging is a prospective solution to enhance the success rate of SCNT.

In most mammalian species, the maturation of an oocyte is the transition from germinal vesicle $(\mathrm{GV})$, the stage in which the heterochromatin ring is clearly observed in the nucleus of the oocyte, to metaphase II (MII), which is arrested until being activated . Metaphase (M-phase) of the oocytes begins with an increase of activated maturation promoting factor (MPF), and the oocyte aging was investigated to be related to the content of activated MPF in the MII-arresting period (Kikuchi et al., 2001). MPF is a heterodimer of cyclin and cyclindependent kinase $(\mathrm{Cdk})$. This molecule is activated 
at germinal vesicle breakdown (GVBD) by the action of phosphatase in late G2 causing dephosphorylation of T14 and Y15 of Cdk2 (p34, Cdc2) (Taieb et al., 1997). Afterward, its content goes up and down as the oocyte enters and exits from M-phase, respectively, during the meiotic cell cycle (Bui et al., 2007). Therefore, maintaining the level of active MPF protein complexes as that in the MI to MII transition or in MII stage is necessary to improve the quality of in vitro mature oocytes used for cloning and subsequent pre-implantation development of the porcine embryos.

Caffeine (1,3,7-trimethylxanthine) is known as a phosphodiesterase inhibitor which has been reported to inhibit Myt1/Wee2 kinase activity leading to the inhibition of the phosphorylation of Cdc2 at T14 and Y15 (Smythe et al., 1992). Therefore, it will enhance the activity of MPF in the oocyte treated with caffeine. The maintaining of MPF activity even after MII-arrested oocytes plays an important role in embryo development. Because of listed reasons, many scientists had applied caffeine treatment to prevent aged oocyte, especially, live young goats were born after caffeine-assisted enucleation (Wang et al., 2011). Furthermore, the caffeine treatment in the last 10 hours of 72-hours-culture on porcine oocytes had increased the MPF activity which was reported to enhance in vitro maturation (IVM) (Kikuchi et al., 2002). Moreover, the caffeine supplementation in the culture medium during the transition from MI to MII period during IVM showed positive results on ovine oocytes and on the total cell number in blastocyst-stage embryos reconstructed by SCNT (Lee, Campbell, 2006). Besides that, the maturation rate and preimplantation development of oocytes were also improved on dromedary oocytes when treated with caffeine (Fathi et al., 2014). In addition, bovine oocytes treated with caffeine during preIVM for $2 \mathrm{~h}$ did not affect the maturation and development of the embryo (Bernal et al., 2016). In spite of positive results from caffeine treatment, some previous researches also showed the negative results. It was reported that after caffeine supplementation during the first 24 hours of pig oocytes IVM, the caffeine inhibited the meiotic resumption through $\mathrm{GV}$ arrest maintaining (Kren et $a l ., 2004)$. In addition, there was no difference in blastocyst development from oocytes after $24 \mathrm{~h}$ of caffeine treatment following $36 \mathrm{~h}$ maturation culture, compared to the control group with $60 \mathrm{~h}$ non-caffeine culture (Iwamoto et al., 2005).
Therefore, it should be elucidated which stage of porcine oocyte is affected by caffeine treatment. To investigate the timely treatment of caffeine to rescue aging oocyte, caffeine was supplemented after in vitro maturation (IVM) or during metaphase I metaphase II (MI - MII) transition. Then, examined the effect of caffeine supplementation on the porcine parthenogenetic embryo development in order to enhance the quality of aging oocytes and to improve the embryo development supporting somatic cell nuclear transfer embryo.

\section{MATERIALS AND METHODS}

\section{Oocyte collection and in vitro maturation}

Porcine ovaries were collected from prepubertal gilts at the local slaughterhouse and transported to the laboratory within $2 \mathrm{~h}$. Antral follicles from 4 to 6 $\mathrm{mm}$ were aspirated to collect the oocytes-cumulusgranulosa cell complexes (OCGs) using $18 \mathrm{G}$ needle. Groups of 10-15 OCGs with multi-layered compact cumulus and homogenous ooplasm were cultured in basic maturation medium (Bui et al., 2007) containing TCM-199 supplemented with $10 \%(\mathrm{v} / \mathrm{v})$ fetal bovine serum, $0.1 \mathrm{IU} / \mathrm{mL}$ human chorionic gonadotropin (hCG), $0.1 \mathrm{mg} / \mathrm{mL}$ sodium pyruvate, and $10 \%(\mathrm{v} / \mathrm{v})$ follicle fluid for $42 \mathrm{~h}$ at $38.5^{\circ} \mathrm{C}, 5 \%$ $\mathrm{CO}_{2}$. After $42 \mathrm{~h}$ of IVM, the cumulus cells were removed in $0.1 \%$ hyaluronidase, and the oocytes extruding the first polar body were selected as mature oocytes.

\section{Oocyte aging and caffeine treatment}

After IVM for $42 \mathrm{~h}$, the mature oocytes were induced aging by keeping in the basic maturation medium without hCG and follicle fluid for $6 \mathrm{~h}$ and 8 $\mathrm{h}$ in the incubator

For caffeine treatment after IVM, mature oocytes were treated with different concentrations of caffeine $(0,5$, and $10 \mathrm{mM})$ during the time of aging $(6 \mathrm{~h}$ and $8 \mathrm{~h})$ to acquire optimal conditions. Then oocyte were activated to examine developmental competence of embryos.

For the caffeine treatment during MI - MII transition, the OCGs were first cultured in basic maturation medium for 27 hours (to Metaphase I stage) and then transferred to basic medium supplemented with $5 \mathrm{mM}$ caffeine for the next 15 hours (from Metaphase I to Metaphase II stage). Then mature oocytes were activated to examine the developmental competence of embryos. 


\section{Parthenogenetic activation}

The oocytes were activated in a field solution composed of $0.3 \mathrm{mM}$ Mannitol, $0.05 \mathrm{mM} \mathrm{CaCl}_{2}$, and $0.1 \mathrm{mM} \mathrm{MgSO} 4$ between two parallel stainless-steel electrodes $(0.5 \mathrm{~mm}$ apart $)$ within a chamber connected to an Electro Cell Fusion Generator (LF201, Nepa Gene). The oocytes were activated by double direct-current (DC) pulses of $100 \mathrm{~V}$ for 100 $\mu \mathrm{s}$. After $6 \mathrm{~h}$ from the time of electro-stimulation, the activated oocytes were fixed in 1:3 (v:v) acetic acid to the ethanol solution for the examination of the chromosome structure. The activated oocytes were stained with $1 \%(\mathrm{w} / \mathrm{v})$ orcein in acetic acid and classified into pronuclear formation (activated) or metaphase II (not activated).

\section{In vitro development of parthenogenetic embryo}

After obtaining the optimal electrical setting for activation, different groups of the fresh mature oocyte, aging oocyte treated caffeine after MII or during MI-MII were activated to examine the embryo development and embryo quality. The activated oocytes were cultured in the mWM306 medium (Thuan et al., 2002) supplemented with 5 $\mu \mathrm{g} / \mathrm{mL}$ Cytochalasin B (CB) for $6 \mathrm{~h}$ to produce the parthenogenetic diploids. After $6 \mathrm{~h}$, the embryos were transferred to $\mathrm{mWM} 306$ medium without CB. The embryos were transferred to mWM256 medium (Thuan et al., 2002) $48 \mathrm{~h}$ after activation and cultured for a total of $168 \mathrm{~h}$. The parthenogenetic embryo development was observed and recorded at 24, 48, 96, 120, and $168 \mathrm{~h}$ after activation, respectively, to different embryo development stages: two-cell, four-cell, eight-cell, early blastocyst, and blastocyst.

\section{Assessment of embryo quality}

The blastocysts were fixed in $4 \%$ paraformaldehyde for $40 \mathrm{~min}$ and permeabilized with $0.2 \%$ Triton $\mathrm{X}-100$ for overnight. The embryos were stained with $2 \mu \mathrm{g} / \mathrm{ml}$ 4,6-diamidino-2phenylindole (DAPI) for $30 \mathrm{~min}$ and the DNA was visualized under a fluorescent microscope to count the cell number in each blastocyst (Bui et al., 2012).

\section{Statistical analysis}

Statistical analysis was performed by Statistical Package for the Social Science Statistics (SPSS) version 22. Statistical differences among groups were analyzed by one-way ANOVA with P-value $<0.05$ that was considered as statistically significant. Three replicates were performed to obtain the data.

\section{RESULTS AND DISCUSSION}

\section{In vitro maturation and parthenogenetic activation of oocytes}

After in vitro culture of $42 \mathrm{~h}$, all of OCGs showed cumulus expansion indicated that oocyte undergoes maturation phase successfully (Figure 1A). The oocytes were denuded of cumulus cells completely by hyaluronidase solution. The extrusion of the first polar body was inspected under an inverted microscopy to assess mature oocyte (Figure 1B). Then oocytes were fixed in Aceto-orcein to examine the meiotic competence of the oocyte. Nucleus morphology of oocyte undergoes this stage: germinal vesicle stage $(\mathrm{GV})$, the first metaphase (MI), the first Anaphase-Telophase (AI-TI) and the second metaphase (MII) (Figure 1C-F). Most of oocytes obtained full meiotic competence reached to MII (79.60\%) and only a small number of oocytes were maintained at GV, MI, AI-TI $(8.46 \%, 5.47 \%$, $2.49 \%$, respectively) and degenerated (3.98\%) Experiment was repeated 4 times with total 201 oocytes.

Mature oocytes with the appearance of the first polar body entrapped within the zona pellucida were used for electro-activation as mentioned in the methods. After Aceto-orcein staining of electrostimulated oocytes, their female pronuclei (FPN) were observed and the FPN formation rates were recorded as the efficiency of the electro-activation (Figure 1G). The pronuclear formation rate was achieved about $90 \%$ in our parthenogenetic activation system.

\section{Effect of caffeine treatment after IVM on aging oocyte}

For caffeine treatment after IVM, mature oocytes were treated with different concentrations of caffeine $(5$ or $10 \mathrm{mM})$ for different periods of time as mentioned in methods, and then oocytes were activated to examine the developmental competence of the embryo.

The development of 2-cell embryos with the caffeine treatment is significantly higher than without treatment in both the $6 \mathrm{~h}$ and the $8 \mathrm{~h}$ (Table 1). However, the number of embryos reduced in longer duration of aging $(8 \mathrm{~h})$ and it was significantly reduced with high concentration of caffeine $(10 \mathrm{mM})$. Therefore, the caffeine treatment with an appropriate concentration of $5 \mathrm{mM}$ was recommended to rescue the oocyte aging. However, 
although caffeine can increase the number of embryos at 4-cell stage, the cytoplasmic homogeneity is significantly reduced in aging oocyte compared to fresh oocyte and it could not improve by caffeine treatment (Figure 2). In addition, there was no significant different in number of eight cell and blastocyst stage in caffeine treated and untreated group (Table 1).
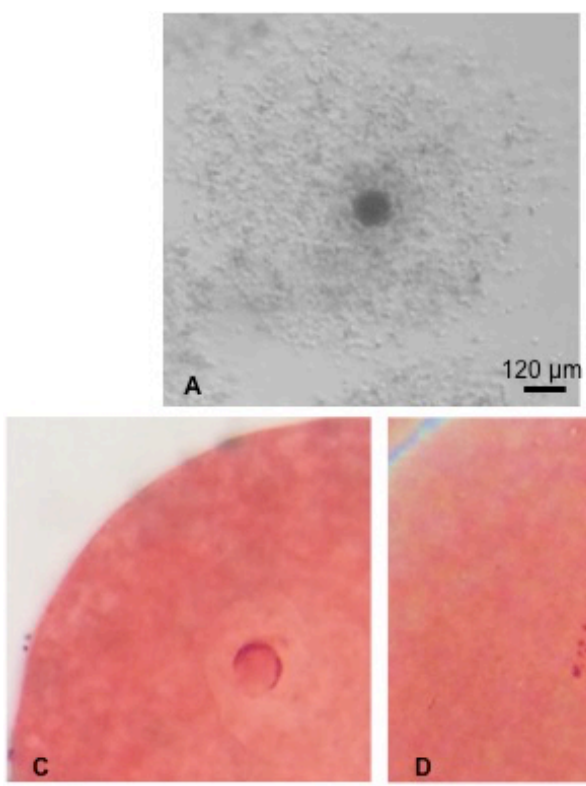

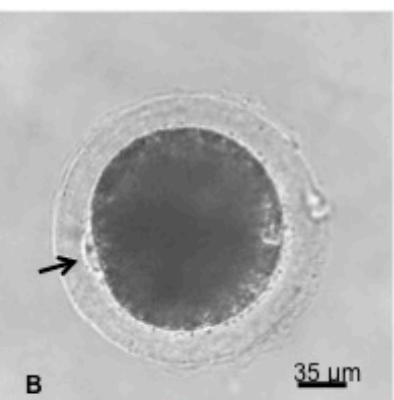

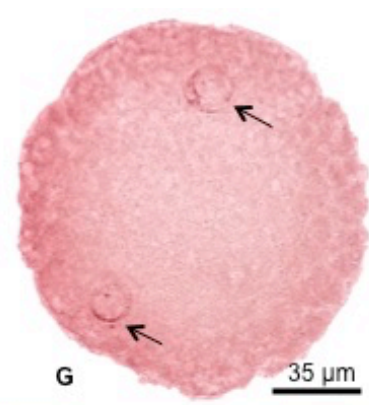

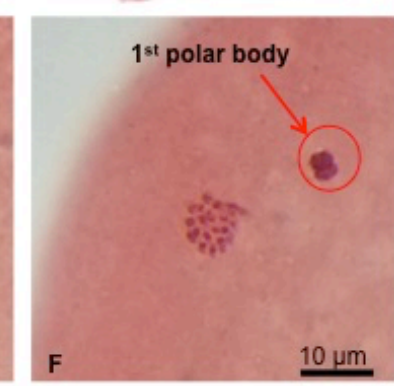

Figure 1. Morphology of porcine oocyte after in vitro maturation (IVM). (A) Expansion of cumulus cell surrounding the oocyte after 42 hours of IVM and (B) Mature oocyte with the extrusion of the first polar body (arrow). (C-F) Nucleus morphology of oocyte undergoes meiotic competence with these stages: Germinal Vesicle (GV, C); Metaphase I (MI, D); Anaphase ITelophase I (AI-TI, E), Metaphase II (MII, F). (G) Successful activation of zygote with two pronuclei (arrows).

Table 1. The developmental competence of parthenogenetic embryos derived from aging oocytes treated caffeine 6-hour and 8-hour.

\begin{tabular}{|c|c|c|c|c|c|c|}
\hline \multirow{2}{*}{ Treatment } & \multirow{2}{*}{$\begin{array}{l}\text { Caffeine } \\
\text { concentrati } \\
\text { on (nM) }\end{array}$} & \multirow{2}{*}{$\begin{array}{l}\text { No. of } \\
\text { oocytes }\end{array}$} & \multicolumn{4}{|c|}{ No. (\%) of embryos } \\
\hline & & & Two-cells & Four-cell & Eight-cell & Blastocyst \\
\hline $\mathrm{Oh}$ & 0 & 87 & $\begin{array}{l}82 \\
(94.25 \pm 1.16)^{\mathrm{a}}\end{array}$ & $\begin{array}{l}71 \\
(81.63 \pm 0.83)^{a}\end{array}$ & $\begin{array}{l}65 \\
(74.73 \pm 0.74)^{a}\end{array}$ & $\begin{array}{l}34 \\
(39.15 \pm 1.89)^{a}\end{array}$ \\
\hline \multirow{3}{*}{$6 \mathrm{~h}$} & 0 & 85 & $\begin{array}{l}57 \\
(67.04 \pm 1.41)^{d}\end{array}$ & $\begin{array}{l}41 \\
(48.23 \pm 1.03)^{\mathrm{e}}\end{array}$ & $\begin{array}{l}35 \\
(41.18 \pm 1.04)^{c}\end{array}$ & $\begin{array}{l}9 \\
(10.59 \pm 0.12)^{d}\end{array}$ \\
\hline & 5 & 74 & $\begin{array}{l}64 \\
(88.95 \pm 3.60)^{\mathrm{ab}}\end{array}$ & $\begin{array}{l}59 \\
(79.78 \pm 0.64)^{\mathrm{ab}}\end{array}$ & $\begin{array}{l}35 \\
(47.53 \pm 1.24)^{b}\end{array}$ & $\begin{array}{l}21 \\
(28.50 \pm 0.89)^{\mathrm{b}}\end{array}$ \\
\hline & 10 & 76 & $\begin{array}{l}65 \\
(85.66 \pm 2.09)^{b}\end{array}$ & $\begin{array}{l}58 \\
(76.16 \pm 2.80)^{b}\end{array}$ & $\begin{array}{l}35 \\
(45.99 \pm 1.20)^{b}\end{array}$ & $\begin{array}{l}13 \\
(17.21 \pm 1.84)^{\mathrm{c}}\end{array}$ \\
\hline \multirow{3}{*}{$8 \mathrm{~h}$} & 0 & 79 & $\begin{array}{l}45 \\
(57.04 \pm 2.36)^{\mathrm{e}}\end{array}$ & $\begin{array}{l}36 \\
(45.67 \pm 1.50)^{\mathrm{e}}\end{array}$ & $\begin{array}{l}30 \\
(37.92 \pm 0.99)^{c}\end{array}$ & $\begin{array}{l}7 \\
(8.94 \pm 1.54)^{\mathrm{de}}\end{array}$ \\
\hline & 5 & 73 & $\begin{array}{l}61 \\
(83.52 \pm 0.59)^{b}\end{array}$ & $\begin{array}{l}52 \\
(71.16 \pm 1.03)^{c}\end{array}$ & $\begin{array}{l}29 \\
(39.65 \pm 1.41)^{c}\end{array}$ & $\begin{array}{l}9 \\
(12.25 \pm 2.07)^{d}\end{array}$ \\
\hline & 10 & 84 & $\begin{array}{l}63 \\
(75.02 \pm 1.88)^{c}\end{array}$ & $\begin{array}{l}55 \\
(65.49 \pm 0.69)^{d}\end{array}$ & $\begin{array}{l}32 \\
(38.04 \pm 2.75)^{c}\end{array}$ & $\begin{array}{l}4 \\
(4.76 \pm 1.19)^{\mathrm{e}}\end{array}$ \\
\hline
\end{tabular}

Within the same column, percentages with different superscripts (a-e) differ significantly. " $n$ ": total number of oocytes examined. 


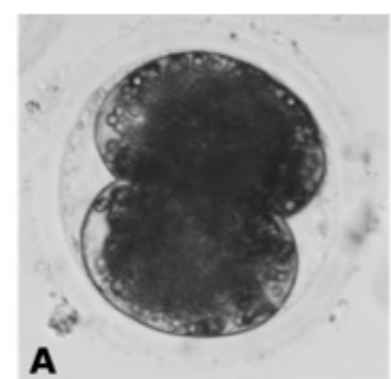

A

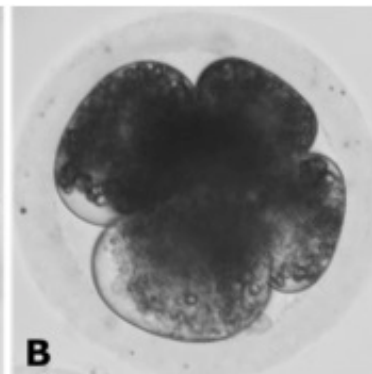

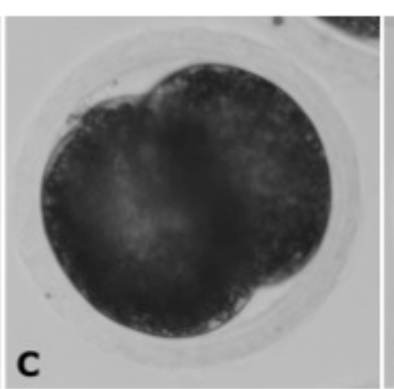

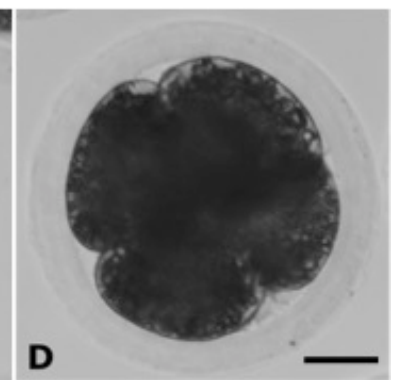

Figure 2. Typical morphology of 2-cell and 4-cell embryos developed from (A, B) Aging oocytes and (C, D) Fresh oocytes. Aging oocytes had non-homogeneous cytoplasm while fresh oocytes have uniform cytoplasm. Scale bar $=35 \mu \mathrm{m}$.

\section{Effect of caffeine treatment during MI-MII transition on aging oocyte}

For the caffeine treatment group, the OCGs were first cultured in basic maturation medium for 27 hours (to MI stage) and then transferred to basic medium supplemented with $5 \mathrm{mM}$ caffeine for the next 15 hours (from MI to MII stage). After IVM, oocytes were examined meiotic competence through expansion of cumulus and extrusion of first polar body as mention in Fig. 1., and there was no significant different in both of caffeine treated and untreated groups. Therefore, the supplementation of caffeine during MI-MII transition has no impact on the maturation rate of oocytes. Then, mature oocytes treated and untreated with caffeine were activated to produce parthenogenetic embryos, then further cultured for development to two-cell, four-cell, eight-cell, early blastocyst and blastocyst stage (Figure 3).

Aging oocytes had led to a significant decrease in the percentage of embryos that could develop to 4cell, 8-cell and blastocyst stage compared to those developed from fresh oocytes $(\mathrm{P}<0.05$, Table 2$)$.
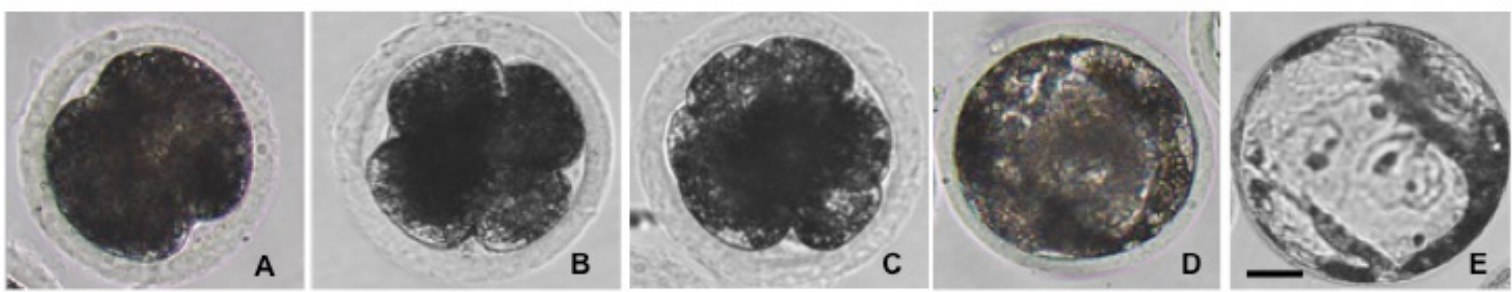

Figure 3. Embryonic developmental stages of parthenogenetic diploid embryos derived from aging oocytes treated with caffeine (A) Two-cell embryo (B) Four- cell embryo (C) Eight-cell embryo (D) Early blastocyst. (E) Blastocyst. Scale bar $=35 \mu \mathrm{m}$.

Table 2. Effects of caffeine supplementation during MI - MII of IVM on subsequent development of parthenogenetic diploid embryos derived from aging oocytes.

\begin{tabular}{|c|c|c|c|c|c|}
\hline \multirow{2}{*}{ Treatment } & \multirow{2}{*}{ Two-cell (n) } & \multicolumn{3}{|c|}{ No. (\%) of embryos } & \multirow{2}{*}{$\begin{array}{l}\text { Total cell number } \\
\text { in blastocyst }\end{array}$} \\
\hline & & Four-cell & Eight-cell & Blastocyst & \\
\hline Fresh oocyte & 93 & $\begin{array}{l}83 \\
(89.27 \pm 0.89)^{a}\end{array}$ & $\begin{array}{l}70 \\
(75.32 \pm 2.61)^{\mathrm{a}}\end{array}$ & $\begin{array}{l}36 \\
(38.73 \pm 0.72)^{a}\end{array}$ & $(73.33 \pm 3.33)^{a}$ \\
\hline Aging oocyte & 92 & $\begin{array}{l}60 \\
(65.23 \pm 1.99)^{b}\end{array}$ & $\begin{array}{l}37 \\
(40.25 \pm 1.54)^{b}\end{array}$ & $\begin{array}{l}10 \\
(10.86 \pm 1.02)^{b}\end{array}$ & $(34.66 \pm 2.33)^{b}$ \\
\hline $\begin{array}{l}\text { Aging oocyte IVM } \\
\text { with } 5 \mathrm{mM} \\
\text { caffeine }\end{array}$ & 92 & $\begin{array}{l}77 \\
(83.73 \pm 2.74)^{a}\end{array}$ & $\begin{array}{l}64 \\
(69.57 \pm 0.95)^{\mathrm{a}}\end{array}$ & $\begin{array}{l}34 \\
(36.95 \pm 0.94)^{\mathrm{a}}\end{array}$ & $(66.00 \pm 2.00)^{a}$ \\
\hline
\end{tabular}

Within the same column, percentages with different superscripts ( $a$ and b) differ significantly. " $n$ ": total number of two-cell embryos. 
The caffeine supplementation during MI to MII had significantly increased the percentage of blastocysts $(36.95 \%)$ compared to groups of aging oocytes without caffeine supplementation $(10.86 \%$, $\mathrm{P}<0.05)$. Importantly, caffeine treatment on aging oocyte can increase the number of blastocyst similar to fresh oocytes (Table 2) and also increase the total cell number in blastocyst (Fig. 4).

There was DNA fragmentation in the blastocysts derived from aging oocytes (Figure 4. A, B), interestingly, caffeine supplementation during MIMII transition could reduce DNA fragmentation in the blastocyst stage (Figure 4.C, D). From previous studies proved that during aging, the DNA fragmentation occurred in mice and human oocytes after in vitro maturation, especially, the fragmentation of DNA appeared in the first polar body and oocyte cytoplasm (Fujino et al., 1996). The correlation of apoptotic death and DNA fragmentation was the main cause for decreased quality of oocytes and lower fertilization in older women (Wu et al., 2000). Therefore, the addition of caffeine during metaphase I to metaphase II can reduce the DNA fragmentation in 6 hours-aging oocytes which is potential for enhancing the quality of embryos and blastocyst implantation ability. This application of caffeine was performed on the parthenogenesis model with duration of 6 hours, an approximately equivalent duration as SCNT takes to finish, with an expectation that it can enhance the success rate of further animal cloning. Agingoocytes is the main reason to decrease the developmental competence of the embryo during in vitro development and also one of the biggest challenges to succeed in SCNT.

The level of MPF molecules has correlation with the oocyte development, the high level of activated MPF expressed in metaphase I and metaphase II mammalian oocytes and its decrease induced by fertilization (Choi et al., 1991). This decreased level of MPF was the trigger for escape from metaphase-II arrest (Taieb et al., 1997). This indicated that maintaining the level of MPF can delay oocyte aging. It showed that caffeine could effectively exert its function to maintain the level of MPF for rescuing aging oocytes (Kikuchi et al., 2001). In detail, the level of MPF protein complex decreased over the time after the oocyte reached the metaphase stage. We demonstrated that caffeine significantly increased in quantity and quality of blastocysts developed from aging oocytes. Therefore, the caffeine treatment during in vitro maturation at metaphase I to metaphase II transition may enhance the success rate of SCNT since the images of embryos developed from aged oocytes with their natural morphologies observed in the study indicated that caffeine is able to fulfill the required priority of safety to use in practical application.

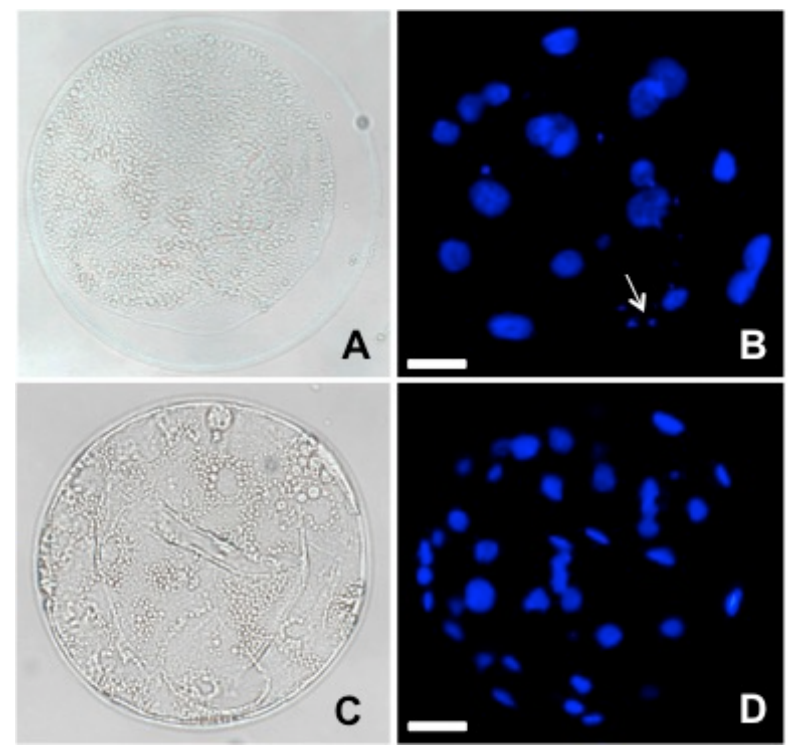

Figure 4. The typical pattern of parthenogenetic diploid blastocyst derived from aging oocytes without and with caffeine supplementation. The DNA was counterstained with DAPI. (A, B) Blastocyst derived from the aging-oocyte without caffeine (A, bright field; B, DAPI), white arrow pointed at DNA fragmentation; (C, D) Blastocyst derived from aging-oocyte with caffeine supplementation (C, bright field; D, DAPI). Scale bar $=30 \mu \mathrm{m}$. 


\section{CONCLUSION}

This study demonstrated that the supplementation of $5 \mathrm{mM}$ caffeine during metaphase I to metaphase II transition on aging oocytes had significantly improved the developmental competence of the embryo to four-cell, eight-cell and blastocyst stage. Especially, caffeine can improve the quality of blastocysts through increasing total cell number and reducing the fragmentation of embryo from aging oocytes. Conclusively, caffeine is a potent chemical for improving the quality of embryo developed from aging oocytes which will be the premise for the success of animal cloning now is ongoing in our laboratory.

Acknowledgment: The authors would like to extend gratitude towards Vissan Joint Stock Company (Ho Chi Minh city) and Ut Hao Slaughterhouse (Di An, Binh Duong) for their supply of porcine ovaries. This research is funded by Vietnam National Foundation for Science and Technology Development (NAFOSTED) under Grant number "106-NN.992015.90; by Vietnam Ministry of Science and Technology under Grant No. ĐTĐL.CN-49/16; by Vietnam National University Ho Chi Minh City (VNU-HCM) under Grant No. B2016-28-01.

\section{REFERENCES}

Bernal-Ulloa SM, Lucas-Hahn A, Herrmann D, Hadeler KG, Aldag P, Baulain U and Niemann H (2016). Oocyte pre-IVM with caffeine improves bovine embryo survival after vitrification. Theriogenology 86(5), 1222-1230.

Bui HT, Van Thuan N, Kishigami S, Wakayama S, Hikichi $\mathrm{T}$, Ohta H, Mizutani E, Yamaoka E, Wakayama $\mathrm{T}$ and Miyano T (2007) Regulation of chromatin and chromosome morphology by histone $\mathrm{H} 3$ modifications in pig oocytes. Reproduction 133: 371-382.

Bui HT, Kwon DN, Kang MH, Oh MH, Park MR, Park WJ, Paik SS, Van Thuan N and Kim JH (2012). Epigenetic reprogramming in somatic cells induced by extract from germinal vesicle stage pig oocytes. Development 139, $4330-4340$.

Choi T, Aoki F, Mori M, Yamashita M, Nagahama Y and Kohmoto K (1991). Activation of p34 cdc2 protein kinase activity in meiotic and mitotic cell cycles in mouse oocytes and embryos. Development 113:789- 795.

Fathi M, Seida AA, Sobhy RR, Darwish GM, Badr MR and Moawad AR (2014) Caffeine supple-mentation during IVM improves frequencies of nuclear maturation and preimplantation develop-ment of dromedary camel oocytes following IVF. Theriogenology 81(9): 1286-1292.

Fujino Y, Ozaki K, Yamamasu S, Ito F, Matsuoka I, Hayashi E, Nakamura H, Ogita S, Sato E and Inoue M (1996) DNA fragmentation of oocytes in aged mice. Hum Reprod 11(7): 1480-1483.

Iwamoto M, Onishi A, Fuchimoto D, Somfai T, Suzuki S, Yazaki S and Kikuchi K (2005). Effects of caffeine treatment on aged porcine oocytes: parthenogenetic activation ability, chromosome condensation and development to the blastocyst stage after somatic cell nuclear transfer. Zygote 13(4), 335-345.

Kikuchi K, Naito K, Noguchi J, Shimada A, Kaneko H, Yamashita Y and Toyoda Y (2001) Maturation M-Phase Promoting Factor: A Regulator of Aging in Porcine Oocytes. Biol Reprod 63(3): 715-722.

Kikuchi K, Naito K, Noguchi J, Kaneko $\mathrm{H}$ and Tojo H (2002) Maturation/M-Phase Promoting Factor Regulates Aging of Porcine Oocytes Matured In vitro. Stem Cells Cloning 4(3): 211-222.

Kren R, Ogushi S, \& Miyano T (2004). Effect of caffeine on meiotic maturation of porcine oocytes. Zygote 12(01), $31-38$

Lee JH and Campbell KHS (2006) Effects of enucleation and caffeine on maturation-promoting factor (MPF) and mitogen-activated protein kinase (MAPK) activities in ovine oocytes used as recipient cytoplasts for nuclear transfer. Biol Reprod 74(4): 691-698.

Smythe C and Newport WJ (1992) Coupling of Mitosis to the Completion of $\mathrm{S}$ Phase in Xenopus Occurs via Modulation of the Tyrosine Kinase That Phosphorylates p34cdc2. Cell 68(4): 787-797.

Taieb F, Chartrain I, Chevalier S, Haccard O and Jessus C (1997) Cyclin D2 Arrests Xenopus Early Embryonic Cell Cycles. Exp Cell Res 237(2): 338-346.

Thuan NV, Kurebayashi S, Harayama H, Nagai T and Miyake M (2002) Stage specific effects of the osmolarity of a culture medium on the development of parthenogenetic diploids in the pig. Theriogenology 59: 719-734.

Wang HL, Chang ZL, Li KL, Lian HY, Han D, Cui W and Tan JH (2011) Caffeine can be used for oocyte enucleation. Cell Reprogram 13(3): 225-232.

Wu J, Zhang L, Wang X (2000) Maturation and apoptosis of human oocytes in vitro are age-related. Fertil Steril 74(6): 1137-1141. 


\title{
CAFFEINE NÂNG CAO KHẢ NĂNG PHÁT TRIỂN CỦA PHÔI TRINH SẢN KÍCH HOẠT TÙ TẾ BÀO TRÚNG LỢN LÃO HÓA
}

\author{
Nguyễn Thị Thùy Vân ${ }^{1,2}$, Phạm Trường Duy ${ }^{1,2}$, Nguyễn Văn Thuận ${ }^{1,2}$, Bùi Hồng Thủy ${ }^{1,2}$ \\ ${ }^{1}$ Phòng Thí nghiệm tái lập trình tế bào, Khoa Công nghệ sinh học, Truò̀ng Đại học Quốc Tế, Thành phố Hồ \\ Chi Minh, Việt Nam \\ ${ }^{2}$ Đại học Quốc gia Thành phố Hồ Chí Minh, Việt Nam
}

\section{TÓM TẮT}

Quá trình lão hóa của tế bào trứng (TBT) xảy ra trong kỹ thuật nhân bản vô tính động vật do thời gian lấy nhân và chuyển nhân kéo dài dẫn đến giảm tỉ lệ sống của phôi. Caffeine đã duy trì nhân tố thúc đẩy trưởng thành (MPF) từ TBT chín (MII), hy vọng sẽ tăng cường chất lượng của TBT lão hóa. Để điều tra thời gian tác động của caffeine lên TBT lão hóa, caffeine được bổ sung sau khi trứng được nuôi chín trong ống nghiệm (IVM) hoặc trong giai đoạn từ metaphase I đến metaphase II (MI - MII). Trước tiên, kiểm tra tác dụng của caffeine sau IVM, MII được gây lão hóa trong vòng 6 hoặc 8 giờ, đồng thời bổ sung các nồng độ caffeine khác nhau $(0,5$ và $10 \mathrm{mM})$ và kiểm tra chất lượng TBT thông qua kích hoạt tạo phôi trinh sản. Mặc dù caffeine có thể cải thiện sự phát triển của phôi từ TBT lão hóa, tuy nhiên, tính đồng nhất tế bào chất giảm đáng kể ở TBT lão hóa so với $\mathrm{TBT}$ tươi và sự cải thiện không đáng kể khi được xử lý bằng caffeine. Tiếp theo, Caffeine đã được bổ sung trong giai đoạn MI - MII của IVM. Sau đó, MII được để lão hóa trong vòng 6 giờ để kiểm tra chất lượng TBT thông qua phôi trinh sản. Kết quả cho thấy $5 \mathrm{mM}$ caffeine bổ sung vào giai đoạn MI-MII đã gia tăng một cách đáng kể sự phát triển của phôi từ TBT lão hóa. Đặc biệt, xử lý bằng caffeine có thể cải thiện tính đồng nhất tế bào chất trong phôi và gia tăng chất lượng phôi nang bằng cách gia tăng số lượng tế bào của phôi từ TBT lão hóa.

Từ khoá: caffeine, tế bào trứng chín, tế bào trứng lão hoá, kích hoạt điện, phôi trinh sản 